\title{
Geochemical Study of Almoqlaq Intrusive Body in North of Asadabad in Hamedan Province, Iran
}

\author{
Ahmad Farnin \\ Islamic Azad University, North Tehran Branch, Tehran, Iran \\ Email: Ahmad.farnin@hotmail.com
}

Received 15 December 2015; accepted 25 January 2016; published 28 January 2016

Copyright (C) 2016 by author and Scientific Research Publishing Inc.

This work is licensed under the Creative Commons Attribution International License (CC BY). http://creativecommons.org/licenses/by/4.0/

c) () Dpen Access

\begin{abstract}
The study area is located in the west of Iran and in the north of Asadabad. This is the range between Eastern lengths of $00^{\prime}, 48^{\circ}$ to $15^{\prime}, 48^{\circ}$, and northern latitudes of $45^{\prime}, 34^{\circ}$ to $00 ', 35^{\circ}$. This range is limited from north to the asphalt road of Hamadan Qorveh, Sanandaj, and from the East and Southeast, to Asadabad of Kermanshah-Hamedan road, and from the West to Chahardoli plain and from the south to the plains and the town of Asadabad. According to the geological map of the study area, intrusive outcropping of diorite-gabbro of Almoqlaq, and quartz syenite is at Almoqlaq mountains. Intrusive rocks of the region, based on the total Alkali oxide, against silica rocks of study area fall within the quartz monzonite, gabbro, granodiorite, granite, and syenite between quartz and alkali granite. And granite in the study area (due to aluminum saturation index), is in the range of metaluminous, and metaluminous to peraluminous. Based on normalized spider diagram with the upper crust, the typical study area belongs to this model, and most of the elements are placed near or on standard line of 1.
\end{abstract}

\section{Keywords}

Almoqlaq, Geochemistry, Intrusion, Alkali Granite, Metaluminous, Quartz Monzonite and Spider Diagram

\section{Introduction}

The study area is located in the west of Iran and in the north of Asadabad. This is the range between Eastern lengths of $00^{\prime}, 48^{\circ}$ to $15^{\prime}, 48^{\circ}$, and northern latitudes of $45^{\prime}, 34^{\circ}$ to $00^{\prime}, 35^{\circ}$ (Figure 1). This range is limited from north to the asphalt road of Hamadan Qorveh, Sanandaj, and from the East and Southeast, to Asadabad of Kermanshah-Hamedan road, and from the West to Chahardoli plain and from the south to the plains and the town of 


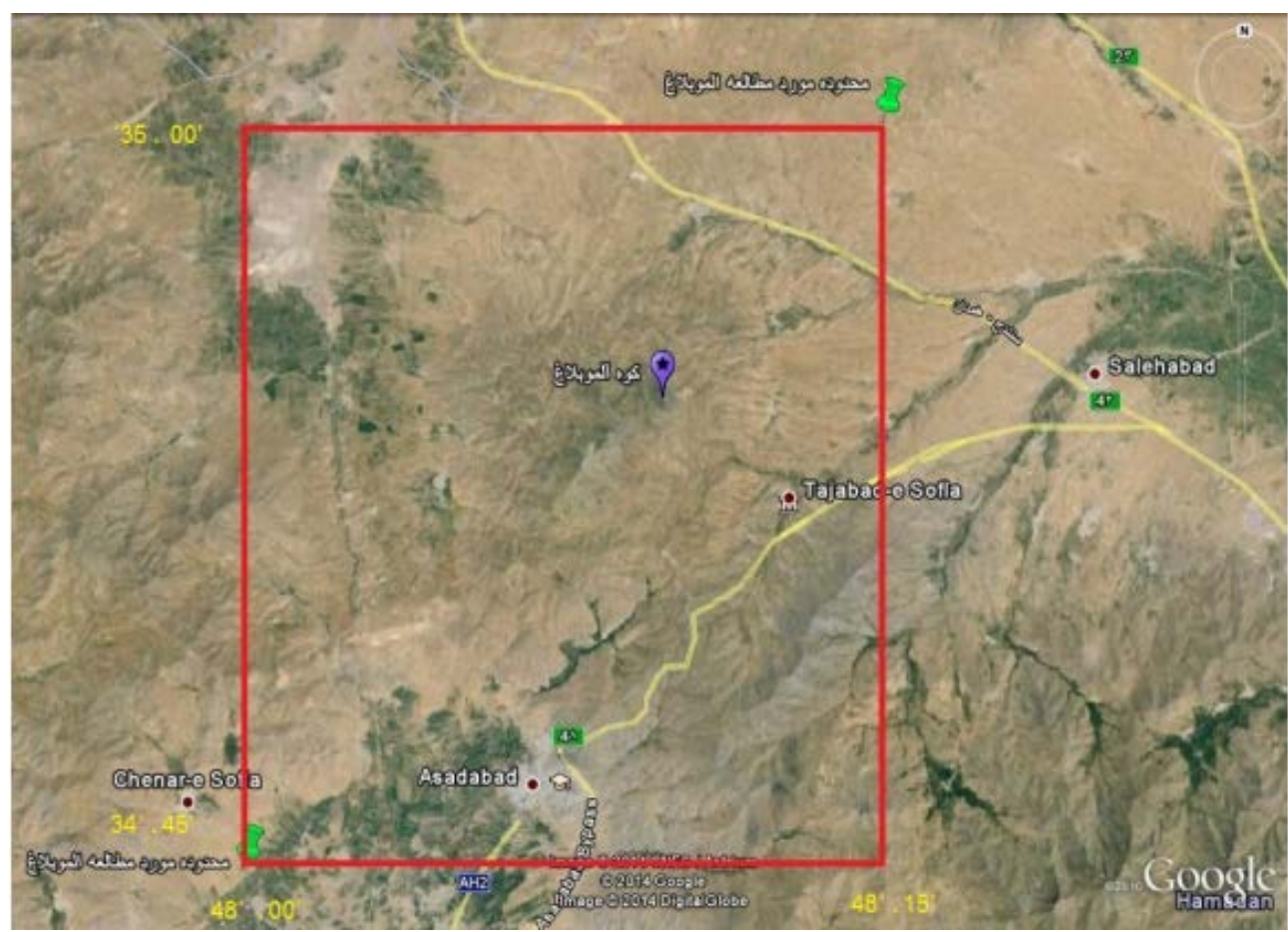

Figure 1. Satellite image of the study area (Source: Google Earth).

Asadabad.

In the north region, there are located Qeshlaq and Pahnebar and Hamekasi; and in the east it is limited to the villages of Ali Baba, Akhtehchi, Lower hand Tajiabad and DEHNO; and from the southeast it is limited to, Rasulabad village; from the west it is limited to the villages of Qarakand, Poshtdarband, Gholdareh, Pirmalu, Charuq; and from the south it is limited to villages of Tarkhinabad and the town of Asadabad (Figure 2).

\section{Access to the Area}

From Hamedan, this area is accessible by two paved roads. One by Hamedan-Asadabad road, in which, the study area is located in its West, and from Hamadan to the highest point of the road in Asadabad Gorge which is about $35 \mathrm{~km}$ away, and from there, via dirt road which was constructed by Department of Telecommunications, and then, by the ways paved for native access, access into the mountains of Almuglaq. Other road is from Hamadan to Sanandaj, from asphalt way to Hamekasi village, with a length of $25 \mathrm{~km}$, and from there, to the village of Baba Ali, and lump iron ore. Also, by dirt-gravel roads, from Asadabad or from Hamekasi village, everyone can access to the plain of Chardoli and to Qarakand village, and then, by a narrow dirt road again to foothills of Almoqlaq (Figure 2).

Almoqlaq peak height is 2993 meters above sea level. Irregularities in the area are in the connection with lithological characteristics and tectonic phenomena, and from the perspective of the formation geomorphological Almoqlaq cone of High Mountain located in the proximity of Mount Alvand, its slope is moderate, and overall appearance is affected by the intrusion of Almoqlaq and evokes a dome-shaped bulge in the mind. Almoqlaq area, from the perspective of structural geology of Iran, is located in Sanandaj-Sirjan and has general characteristics of this zone.

\section{Intrusive Bodies of Study Area}

\subsection{Almoqlaq Masses of Diorite-Gabbro}

This mass is exposed at three points, but from the perspective of development, is much smaller than the mass of Alvand gabbro. Among these deposits, there are a number of dikes or Apophyses with microdioritic-dolerite combinations, which have genetic ties with the masses of diorite-gabbro of Almoqlaq. Stones related to the mass 


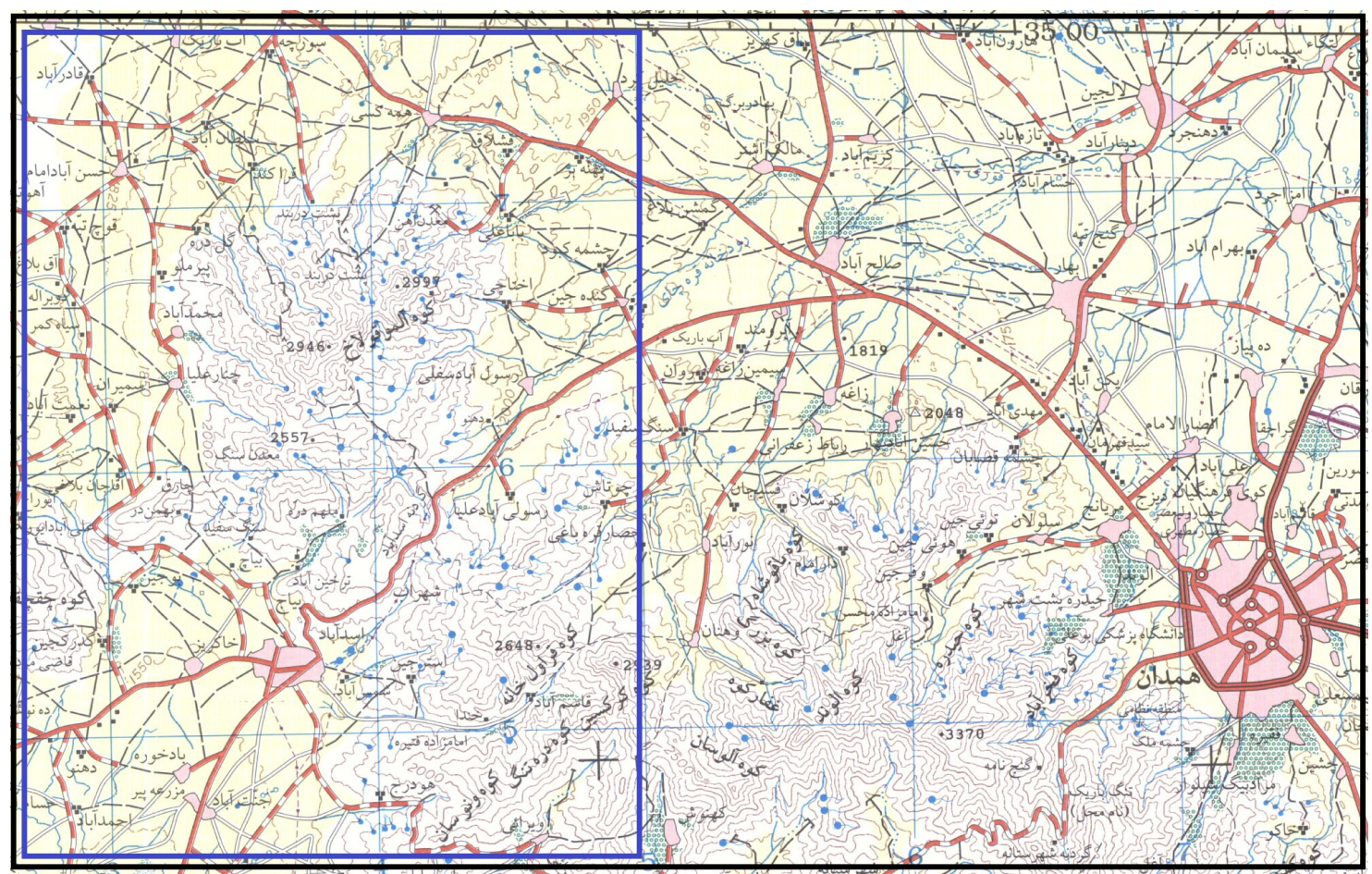

Figure 2. Map of access roads to the study area (topographic map 1:250,000 Hamadan, Armed Forces Geographical Organization, 2001; (Source: Google Earth).

are more likely from gray to light gray with green and sometimes dark spots.

\subsection{Mass of Quartz Syenite in the Mountains of Almoqlaq}

In Almoqlaq Mountains, there are many outcrops of quartz syenite rocks which are a combination of different cognitive stone, inclusind quartz syenite, granodiorite and quartz micro Monsosyenite. These rocks have gentle topography and for the most part, they are covered by debris. The results can be found in the following Tables 1-3 and figures.

\section{Observations and Results}

In the diagram [1], it is used of alkali oxides $\left(\mathrm{Na}_{2} \mathrm{O}+\mathrm{K}_{2} \mathrm{O}\right)$ in the silica of $\mathrm{SiO}_{2}$ (Figure 3). As we can see in the diagram, ten samples were used namely, four samples in quartz monzonite border, one sample in monzonite and a sample in monzonite quartz border a sample is located on the border of quartz monzonite and granite, two located within granite, a sample is located in granite and granodiorite border and a sample located within the gabbro.

Delarosh et al. classification (1980) is based on cationic core elements ratios, and expressed as mg cation. In this category, the results are plotted on a graph of two variables of XY and using graphical parameters of R1, R2. In this diagram, $\mathrm{R} 1$ is placed in the $\mathrm{X}$-axis, and $\mathrm{R} 2$ is located $\mathrm{Y}$-axis. The cation graph defined by R2, R1, which is $=4 \mathrm{Si}-11(\mathrm{Na}+\mathrm{K})-2(\mathrm{Fe}+\mathrm{Ti}) \mathrm{R} 1$ and $\mathrm{R} 2=6 \mathrm{Ca}+2 \mathrm{Mg}+\mathrm{Al}$. Based on the chart below four samples of rocks studied area, ranging from quartz monzonite a sample of gabbro, a sample is within the granodiorite, three are in the range of granite, and an example is in the range between quartz alkali syenite and granite (Figure 4).

Change plot of $\mathrm{K}_{2} \mathrm{O}$ versus $\mathrm{SiO}_{2}$ are presented by changes in weight percentage, the two oxide $\mathrm{K}_{2} \mathrm{O}$ and $\mathrm{SiO}_{2}$, and it has been shown, 4 magmatic series tholeiitic, calc-alkaline, calc-alkaline which are rich in potassium and Shoshsonitic. According to this chart, two samples of rocks are located in tholeites range, two are in the range of calc-alkaline series, six samples are located in the series of calc-alkaline and rich in potassium (Figure 5).

In the classification of rocks on chart, (PQ chart Debon \& Le Fort) was used by parameters $\mathrm{P}=\mathrm{K}-(\mathrm{Na}+\mathrm{Ca})$ and $\mathrm{Q}=\mathrm{Si} / 3-(\mathrm{K}+\mathrm{Na}+2 \mathrm{Ca} / 3)$. With regard to this chart of the rocks in studied area, there are placed a sample 


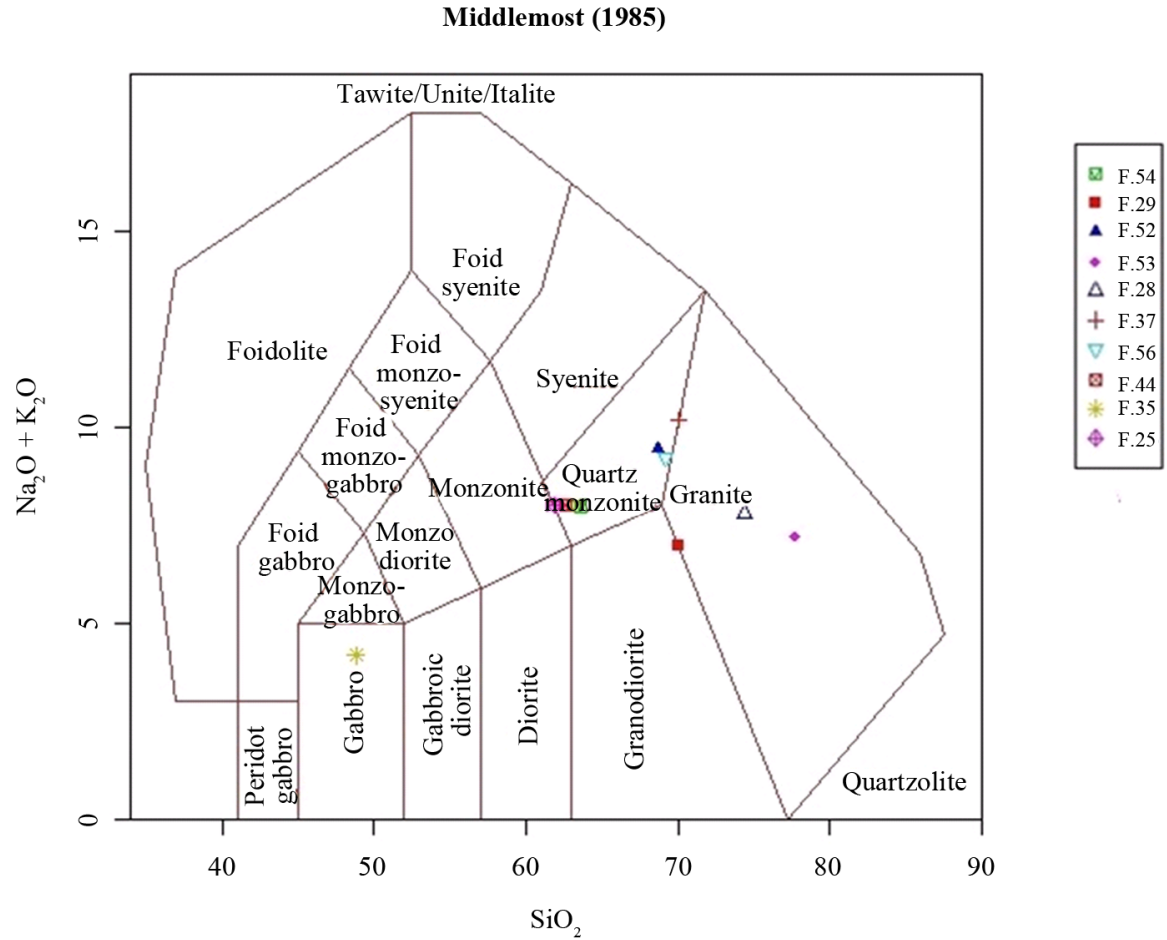

Figure 3. Total alkali oxide $\left(\mathrm{Na}_{2} \mathrm{O}+\mathrm{K}_{2} \mathrm{O}\right)$, against silica $\left(\mathrm{SiO}_{2}\right)$ [1].

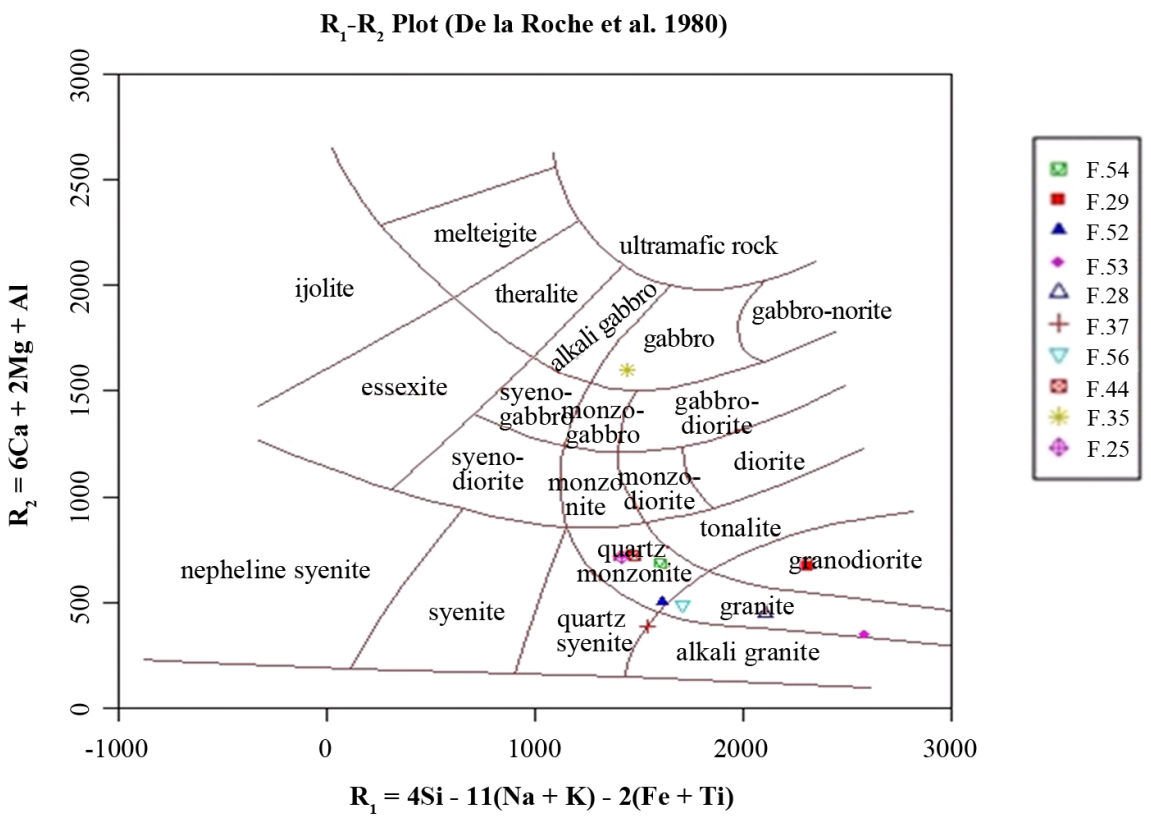

Figure 4. Classification charts of Delarosh et al., 1980 [2].

of gabbro, two of tonalite, a sample of granodiorite sample, two samples of quartz monzonite, three samples of quartz, and one sample are located out of the defined range (Figure 6).

Wilson classification [2]: the base of this classification is the chart of total alkali versus silica (TAS) of Cox et al. (1979), for volcanic rocks which by Wilson [2] has been extended to intrusive rocks. Existing the separating line in alkaline range from sub-alkali, is a feature of this chart. In this diagram (Figure 7), of the rocks of studied area, four samples are located in the range of intermediate, five samples are located in granite range (acidic), and 


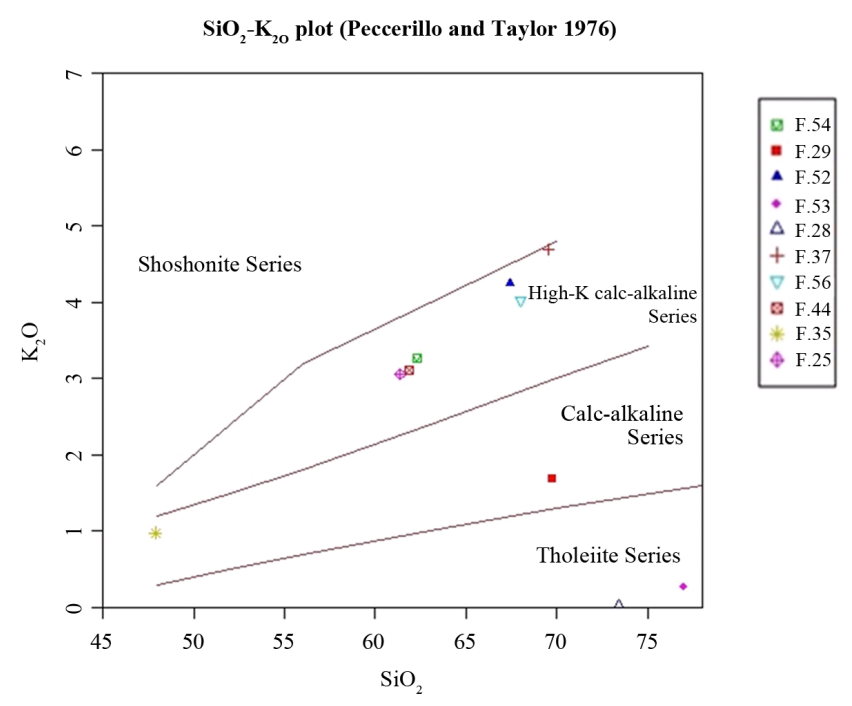

Figure 5. Change plot of $\mathrm{K}_{2} \mathrm{O}$ versus $\mathrm{SiO}_{2}$ (Peccerillo and Taylor, 1976) [2].

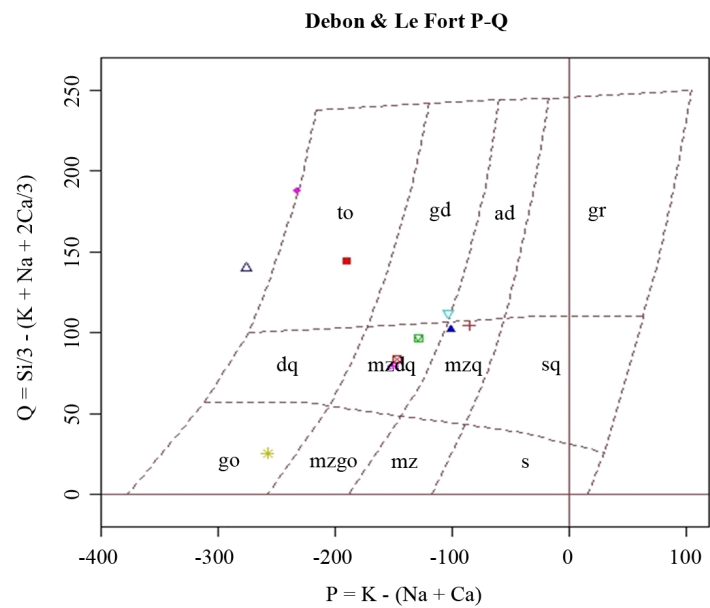

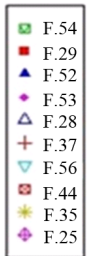

Figure 6. Classification of rocks based on the diagram (Debon \& Le Fort PQ) [2]

Table 1. Chemical analysis of the main elements of the study area (author finding).

\begin{tabular}{cccccccccccc}
\hline S.N. & F.52 & F.29 & F.53 & F.25 & F.54 & F.28 & F.56 & F.35 & F.44 & F.37 \\
\hline Formula & $(\%)$ & $(\%)$ & $(\%)$ & $(\%)$ & $(\%)$ & $(\%)$ & $(\%)$ & $(\%)$ & $(\%)$ & $(\%)$ & 69.52 \\
$\mathrm{SiO}_{2}$ & 67.41 & 69.76 & 76.96 & 61.39 & 62.32 & 73.42 & 68.03 & 47.89 & 61.85 & 69.52 \\
$\mathrm{Al}_{2} \mathrm{O}_{3}$ & 15.34 & 16.21 & 12.73 & 16.15 & 15.96 & 13.69 & 15.24 & 14.53 & 16.11 & 15.84 \\
$\mathrm{Fe}_{2} \mathrm{O}_{3}$ & 3.34 & 2.41 & 0.92 & 7.56 & 6.42 & 1.53 & 3.23 & 14.86 & 6.82 & 2.43 \\
$\mathrm{CaO}$ & 1.63 & 3.11 & 0.89 & 3.26 & 2.89 & 1.59 & 1.45 & 9.98 & 3.21 & 0.55 \\
$\mathrm{Na}_{2} \mathrm{O}$ & 5.03 & 5.26 & 6.89 & 4.88 & 4.52 & 7.69 & 5.04 & 3.12 & 4.82 & 5.42 \\
$\mathrm{~K}_{2} \mathrm{O}$ & 4.25 & 1.69 & 0.27 & 3.06 & 3.26 & 0.02 & 4.02 & 0.98 & 3.11 & 4.69 \\
$\mathrm{MgO}$ & 0.48 & 0.44 & 0.15 & 0.96 & 1.18 & 0.27 & 0.69 & 4.96 & 1.29 & 0.32 \\
$\mathrm{TiO}_{2}$ & 0.561 & 0.542 & 0.191 & 1.334 & 0.968 & 0.493 & 0.451 & 1.536 & 1.201 & 0.352 \\
$\mathrm{MnO}$ & 0.048 & 0.021 & 0.005 & 0.123 & 0.115 & 0.016 & 0.067 & 0.146 & 0.147 & 0.007 \\
$\mathrm{P}_{2} \mathrm{O}_{5}$ & 0.076 & 0.083 & 0.028 & 0.421 & 0.271 & 0.044 & 0.076 & 0.088 & 0.198 & 0.061 \\
$\mathrm{~S}$ & 0.008 & 0.006 & 0.008 & 0.006 & 0.005 & 0.008 & 0.009 & 0.012 & 0.007 & 0.006 \\
$\mathrm{~L} . \mathrm{O} . \mathrm{I}$ & 1.63 & 0.24 & 0.59 & 0.56 & 1.79 & 0.93 & 1.32 & 1.54 & 1.08 & 0.55 \\
\hline
\end{tabular}


Table 2. Normative composition in the samples of study area (author finding).

\begin{tabular}{cccccccccccc}
\hline Sample & F.52 & F.29 & F.53 & F.25 & F.54 & F.28 & F.56 & F.35 & F.44 & F.37 \\
\hline Q & 18.079 & 25.26 & 34.062 & 14.129 & 16.365 & 25.97 & 19.407 & 3.116 & 13.991 & 18.561 \\
C & 0 & 0.272 & 0 & 0 & 0.39 & 0 & 0.143 & 0 & 0 & 0.993 \\
Or & 25.116 & 9.987 & 1.596 & 18.084 & 19.266 & 0.118 & 23.757 & 5.791 & 18.379 & 27.716 \\
Ab & 42.562 & 44.509 & 58.301 & 41.293 & 38.247 & 65.071 & 42.647 & 26.401 & 40.786 & 45.863 \\
An & 6.725 & 14.887 & 3.01 & 13.124 & 12.567 & 2.777 & 6.697 & 22.747 & 13.136 & 2.33 \\
Di & 0 & 0 & 0.434 & 0 & 0 & 1.451 & 0 & 16.627 & 0 & 0 \\
Wo & 0 & 0 & 0 & 0 & 0 & 0.531 & 0 & 0 & 0 & 0 \\
Hy & 1.196 & 1.096 & 0.172 & 2.391 & 2.939 & 0 & 1.719 & 4.646 & 3.213 & 0.797 \\
Il & 0.084 & 0.031 & 0 & 0.249 & 0.234 & 0.015 & 0.122 & 0.284 & 0.298 & 0.001 \\
Hm & 3.34 & 2.41 & 0.92 & 7.56 & 6.42 & 1.53 & 3.23 & 14.86 & 6.82 & 2.43 \\
Tn & 0.609 & 0 & 0.469 & 0.211 & 0 & 1.19 & 0 & 3.404 & 1.054 & 0 \\
Ru & 0.269 & 0.526 & 0 & 1.118 & 0.845 & 0 & 0.387 & 0 & 0.615 & 0.352 \\
Ap & 0.18 & 0.197 & 0.066 & 0.997 & 0.642 & 0.104 & 0.18 & 0.208 & 0.469 & 0.144 \\
Pr & 0.015 & 0.011 & 0.008 & 0.011 & 0.009 & 0.015 & 0.017 & 0.022 & 0.013 & 0.011 \\
Sum & 98.176 & 0.011 & 99.039 & 99.166 & 97.924 & 98.772 & 98.306 & 98.106 & 98.774 & 99.198 \\
\hline
\end{tabular}

Table 3. The results of chemical analysis for trace elements, in the samples of the study area (in ppm) (author finding).

\begin{tabular}{|c|c|c|c|c|c|c|c|c|c|c|}
\hline Field num. & F.52 & F.29 & F.53 & F.25 & F.54 & F.28 & F.56 & F.35 & F.44 & F.37 \\
\hline $\mathrm{Cl}$ & 274 & 98 & 87 & 214 & 2215 & 54 & 324 & 4924 & 4028 & 136 \\
\hline $\mathrm{Ba}$ & 542 & 368 & 280 & 660 & 565 & 380 & 512 & 334 & 680 & 343 \\
\hline $\mathrm{Sr}$ & 172 & 480 & 133 & 293 & 165 & 105 & 134 & 227 & 169 & 27 \\
\hline $\mathrm{Cu}$ & 13 & 21 & 24 & 25 & 20 & 17 & 20 & 31 & 23 & 41 \\
\hline $\mathrm{Zn}$ & 58 & 27 & 18 & 89 & 88 & 27 & 53 & 66 & 85 & 31 \\
\hline $\mathrm{Pb}$ & 8 & 7 & 16 & 5 & 14 & 6 & 9 & 8 & 18 & 19 \\
\hline $\mathrm{Ni}$ & 38 & 37 & 40 & 40 & 36 & 43 & 31 & 63 & 34 & 39 \\
\hline $\mathrm{Cr}$ & 8 & 9 & 11 & 9 & 5 & 7 & 5 & 31 & 7 & 5 \\
\hline V & 50 & 63 & 25 & 104 & 115 & 57 & 52 & 325 & 122 & 42 \\
\hline Ce & 85 & 49 & 51 & 22 & 43 & 59 & 49 & 35 & 89 & 49 \\
\hline $\mathrm{La}$ & 28 & 22 & 28 & 8 & 21 & 30 & 22 & 14 & 32 & 19 \\
\hline $\mathrm{W}$ & 8 & 5 & 4 & 8 & 14 & 6 & 6 & 5 & 2 & 2 \\
\hline $\mathrm{Zr}$ & 460 & 565 & 344 & 347 & 395 & 430 & 430 & 86 & 328 & 496 \\
\hline $\mathrm{Y}$ & 73 & 61 & 58 & 72 & 71 & 131 & 68 & 22 & 60 & 79 \\
\hline $\mathrm{Rb}$ & 117 & 43 & 23 & 76 & 103 & 16 & 112 & 38 & 107 & 131 \\
\hline Co & 8 & 5 & 11 & 8 & 12 & 9 & 11 & 9 & 12 & 8 \\
\hline As & 2 & 11 & 21 & 5 & 4 & 42 & 5 & 5 & 7 & 19 \\
\hline $\mathrm{U}$ & 6 & 2 & 1 & 2 & 8 & 2 & 2 & 1 & 2 & 1 \\
\hline Th & 11 & 8 & 15 & 8 & 14 & 11 & 9 & 4 & 6 & 15 \\
\hline Mo & 1 & 2 & 2 & 1 & 1 & 2 & 4 & 2 & 6 & 5 \\
\hline $\mathrm{Ga}$ & 22 & 27 & 18 & 19 & 20 & 30 & 20 & 13 & 17 & 23 \\
\hline $\mathrm{Nb}$ & 1 & 2 & 4 & 2 & 1 & 5 & 2 & 1 & 1 & 2 \\
\hline
\end{tabular}




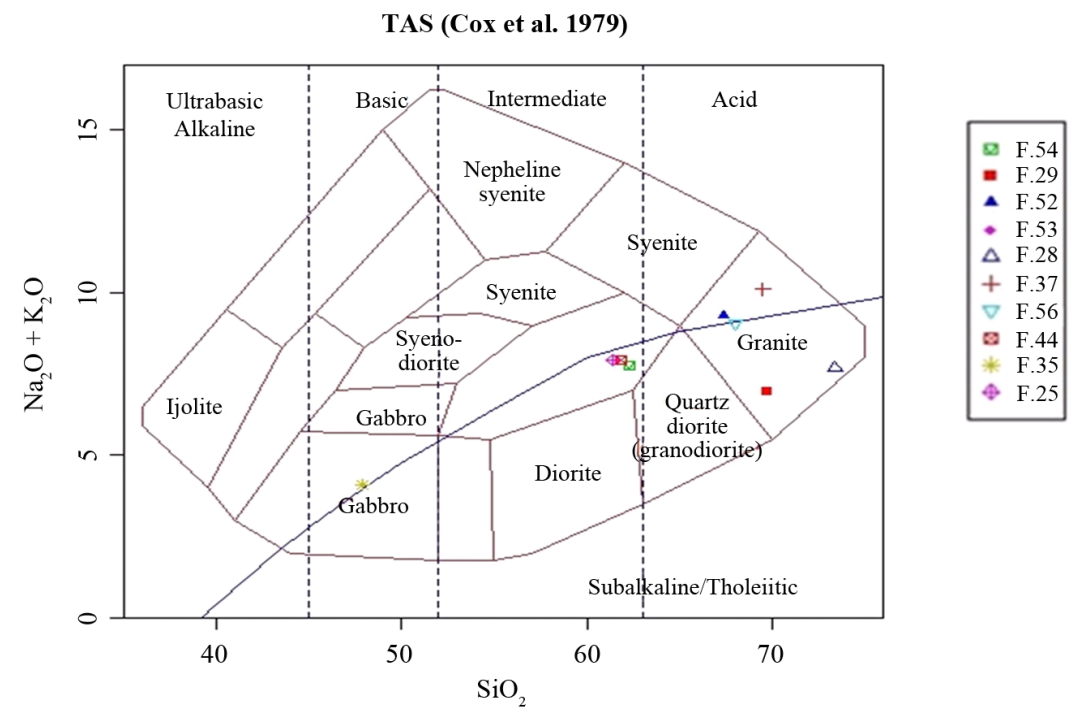

Figure 7. Geochemical classification of intrusive rocks using total figure of Alkali against silica (Cox et al., 1979) [2].

a sample is gabbro rocks and is located in basic range.

Classification of rocks based on Debon \& Le Fort $\mathrm{AB}$ chart: This graph covers $\mathrm{A}=\mathrm{Al}-(\mathrm{K}+\mathrm{Na}+2 \mathrm{Ca})$ and $\mathrm{B}=\mathrm{Fe}+\mathrm{Mg}+\mathrm{Ti}$ parameters which is indicative of two ranges of Peraluminous and metaluminous. According to below diagram, three of the rocks are located in the study area of metaluminous, and contain biotite \pm amphibole \pm pyroxene Clino, four rock samples from the study area are located in the meta area, and the are composed of biotite, amphibole \pm pyroxene, two are located on the border of Peraluminous and metaalumina (3 and 4 ) and the range includes biotite, amphibole, pyroxene and biotite \pm a little bit of amphibole. One of the rocks range. one of the rocks of the study area is in the region of Peraluminous, and is located on the border of 2 and 3, which includes biotite \pm a small amount of amphibole, muscovite and biotite. See Figure 8.

Classification of rocks based on (Alkali-Lime): In this graph which is introduced in the name of MALI, parameters of $\left(\mathrm{Na}_{2} \mathrm{O}+\mathrm{K}_{2} \mathrm{O}\right)$, in front of $\mathrm{SiO}_{2}$ (Figure 9) are used. In this diagram, nine samples are in the range of calcite and a sample is placed in the alkaline range.

Todays, the saturation of aluminum has been accepted as an important factor in determining the origin of granitoid magma and is of particular importance. Based on this index, peraluminous granites are divided into 4 categories of metaluminous, Peralkaline and sub-alumina [3].

PerAlumina $\mathrm{Al}_{2} \mathrm{O}_{3}>\left(\mathrm{Na}_{2} \mathrm{O}+\mathrm{K}_{2} \mathrm{O}+\mathrm{CaO}\right)$

Metaluminous $\left(\mathrm{Na}_{2} \mathrm{O}+\mathrm{K}_{2} \mathrm{O}+\mathrm{CaO}\right)>\mathrm{Al}_{2} \mathrm{O}_{3}>\left(\mathrm{Na}_{2} \mathrm{O}+\mathrm{K}_{2} \mathrm{O}\right)$

Saab alumina $\mathrm{Al}_{2} \mathrm{O}_{3}=\left(\mathrm{Na}_{2} \mathrm{O}+\mathrm{K}_{2} \mathrm{O}\right)$

Peralkaline $\mathrm{Al}_{2} \mathrm{O}_{3}<\left(\mathrm{Na}_{2} \mathrm{O}+\mathrm{K}_{2} \mathrm{O}\right)$

Aluminium saturation index is defined by the following relationship:

$\mathrm{Al} / \mathrm{NK}=\mathrm{Al}_{2} \mathrm{O}_{3} /\left(\mathrm{Na}_{2} \mathrm{O}+\mathrm{K}_{2} \mathrm{O}\right)$

$\mathrm{Al} / \mathrm{CNK}=\mathrm{Al}_{2} \mathrm{O}_{3} /\left(\mathrm{Na}_{2} \mathrm{O}+\mathrm{K}_{2} \mathrm{O}+\mathrm{CaO}\right)$

Based on the chart [3], seven samples are in the range of meta-alumina and two samples are on the border of meta-alumina to per-alumina, a sample located within Peraluminous (Figure 10).

Normalized graph of the area under study, with normal Mvrbhay, Sun \& MacDonough 1989 [4]: According to this model, elements LILE) Rb, K (Ba, and light rare earths (LREE) (Ce, La), compared to the elements (Nb, Ti) HFS, enriched show, and in our model, most chemicals, placed on top of the standard line 1, the MORB. In this pattern, anomalies $\mathrm{Pb}$ observed. Based on these charts, examples area of study, depletion of elements $\mathrm{P}, \mathrm{Ti}$, and enriched $\mathrm{Pb}$, and almost all elements, are higher than the standard line 1, the MORB, that this issue shows a lack of independence of the mantle source depleted (MORB) (Figure 11).

To evaluate changes in productive magma toward original one, as well as their origin and genetic relationship, the spider diagrams was used. According to this model, nearly all elements show enrichment, such as Th, U, Rb, with the exception of potassium, compared to primitive mantle. Enrichment of samples in the range of LILE, 


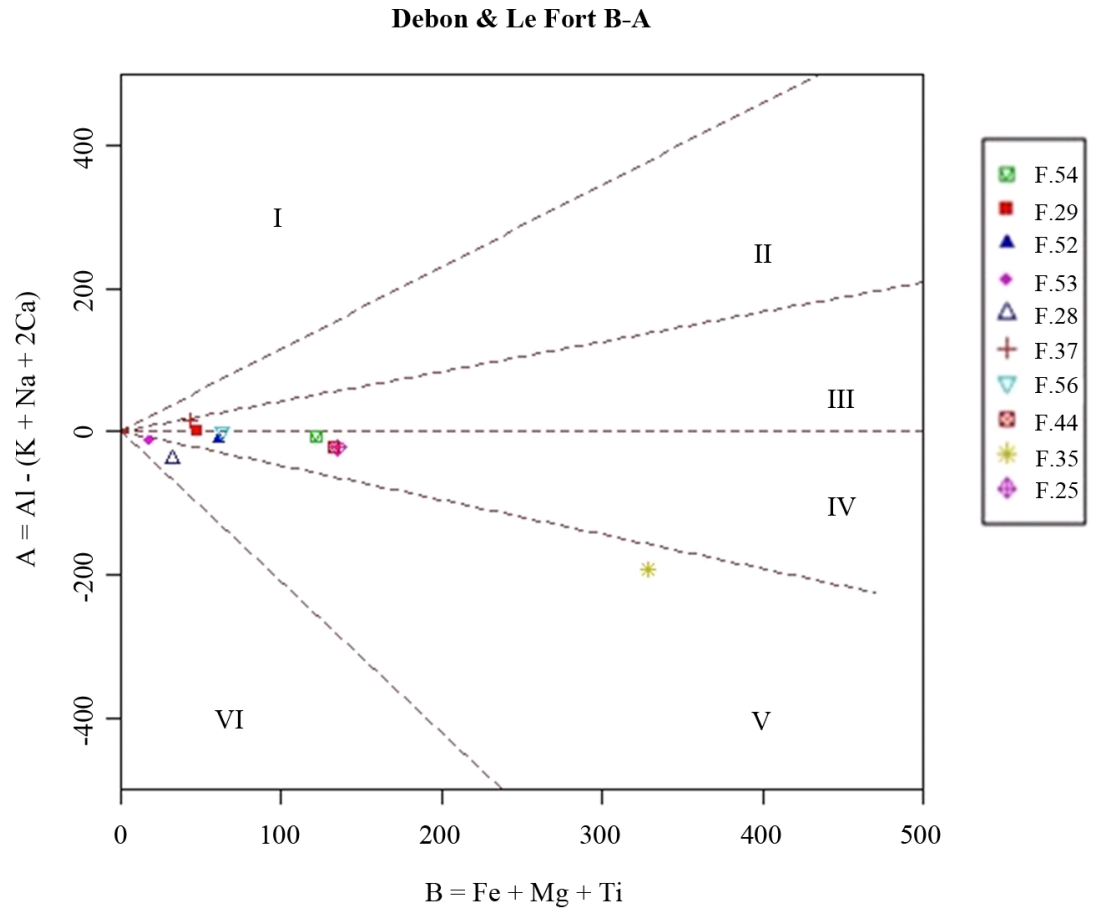

Figure 8. Classification of rocks, according to the chart A (B) Debon \& Le Fort [3].

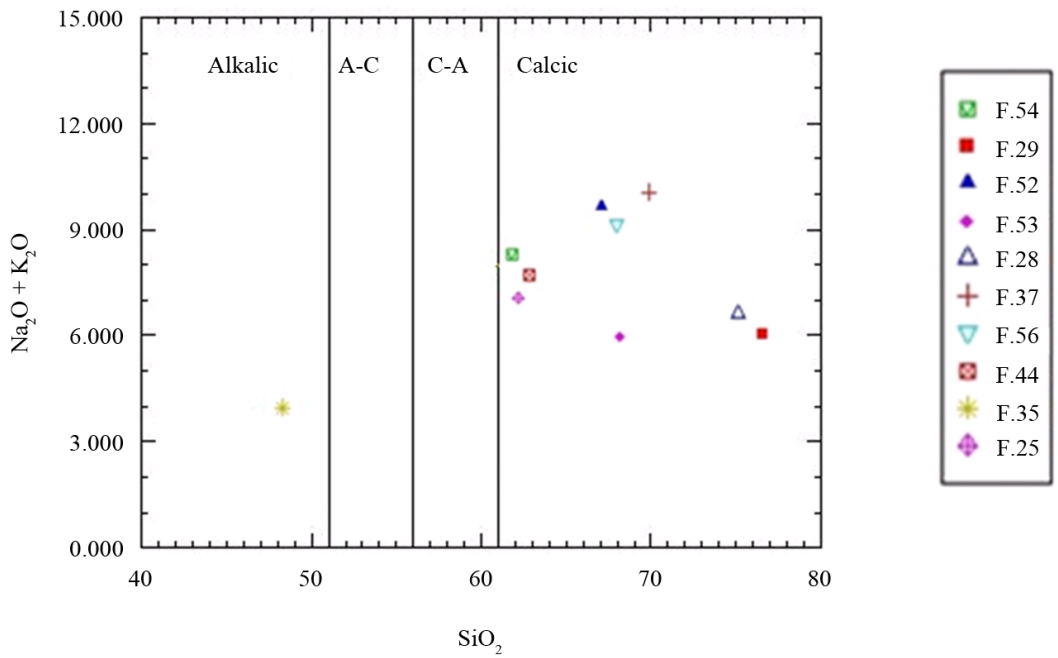

Figure 9. Classification based on Alkali-Lime (Peacock, 1931) Aluminium saturation index [3].

could be the result of magma fractionation and crustal contamination. Elements of $\mathrm{Zr}$, Th, $\mathrm{Y}$, have a positive anomaly, and these elements can indicate infection with the upper crust (Figure 12).

According to this model, the $\mathrm{Nb}$ element has negative anomaly, and to the upper crust, suggesting the depletion. Elements of $\mathrm{Y}, \mathrm{Zr}$ are also central to the case, which has enriched and the positive anomalies of these elements may indicate infection with the upper crust. Most elements are near or on the standard line 1, the Upper crust (Figure 13).

\section{Conclusions}

According to petrographic studies, most igneous rocks of the study area, such as: Quartz syenite, which is a 
A/CNK-A/NK plot (Shand 1943)

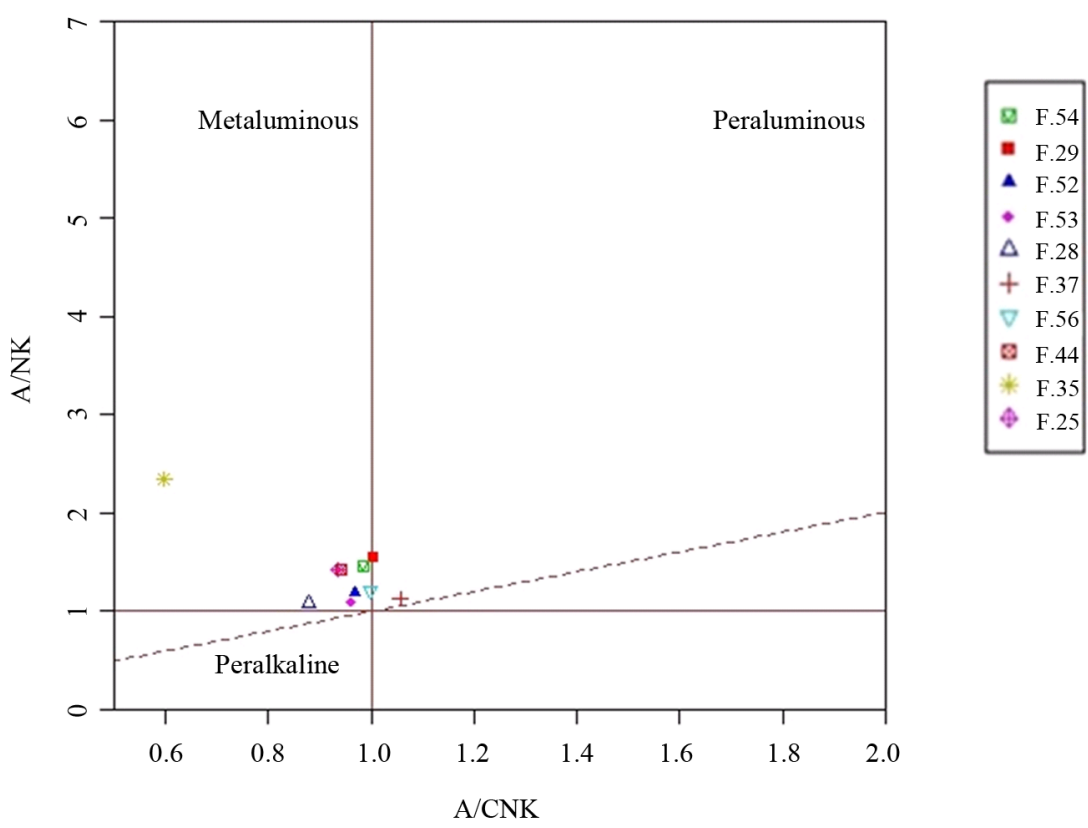

Figure 10. The chart of $\mathrm{A} / \mathrm{NK}$ against $\mathrm{A} / \mathrm{CNK}$ to distinguish peraluminous, metaluminous and Peralkaline magmas [3].

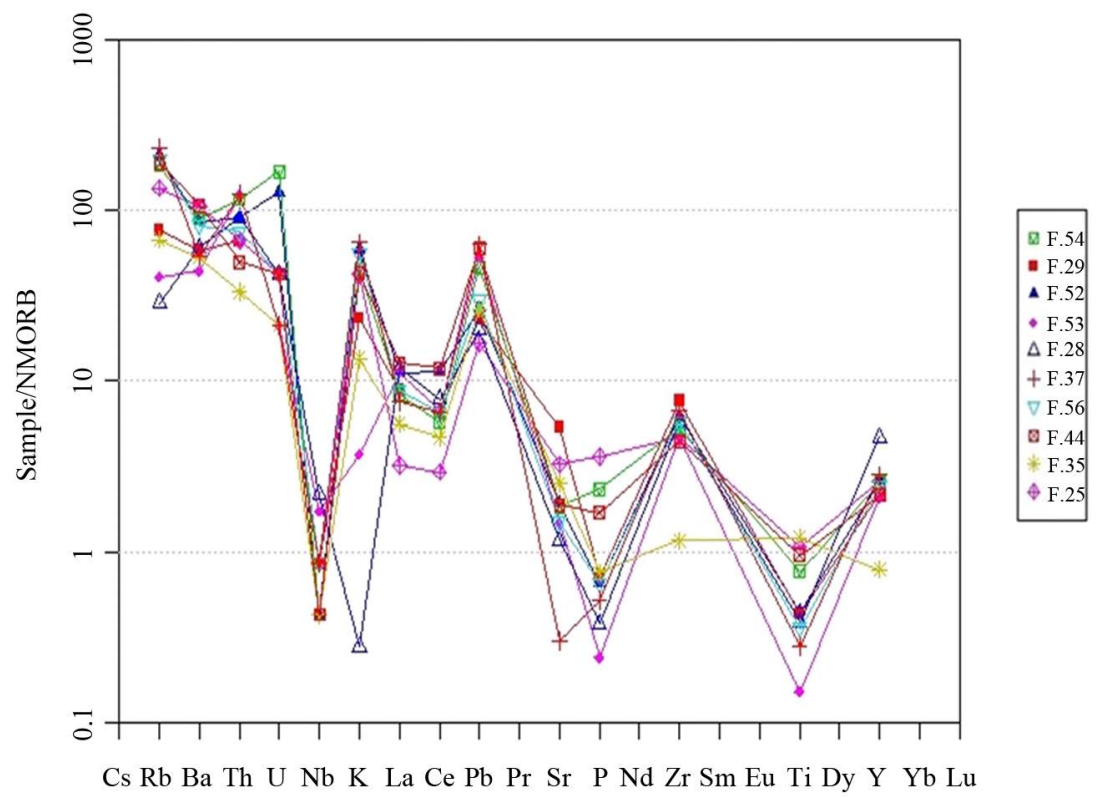

Figure 11. The normalized spider diagrams, from the study area samples with normal diagonals [4].

medium-grained texture and porphyric. Syenite and quartz syenite and plutonic rocks form the bulk of the region. Quartz hornblende syenite is a medium-grained texture, and little alteration in them. The stone, after the quartz syenite, forms the largest rocks in the study area. Alkali granite studied, mostly middle-crystal, is a Porphyric tissue, the tissue indicating shallow magma crystallization, and is often helococrate, or Lococrate. Other gems of the study area, syenite, are without quartz or quartz-poor, and pure tissue. Alkaline quartz syenite, this stone is structured grain. Monzonite, monzonite of the area is gray, and has an average grain texture. Hornblende diorite, 


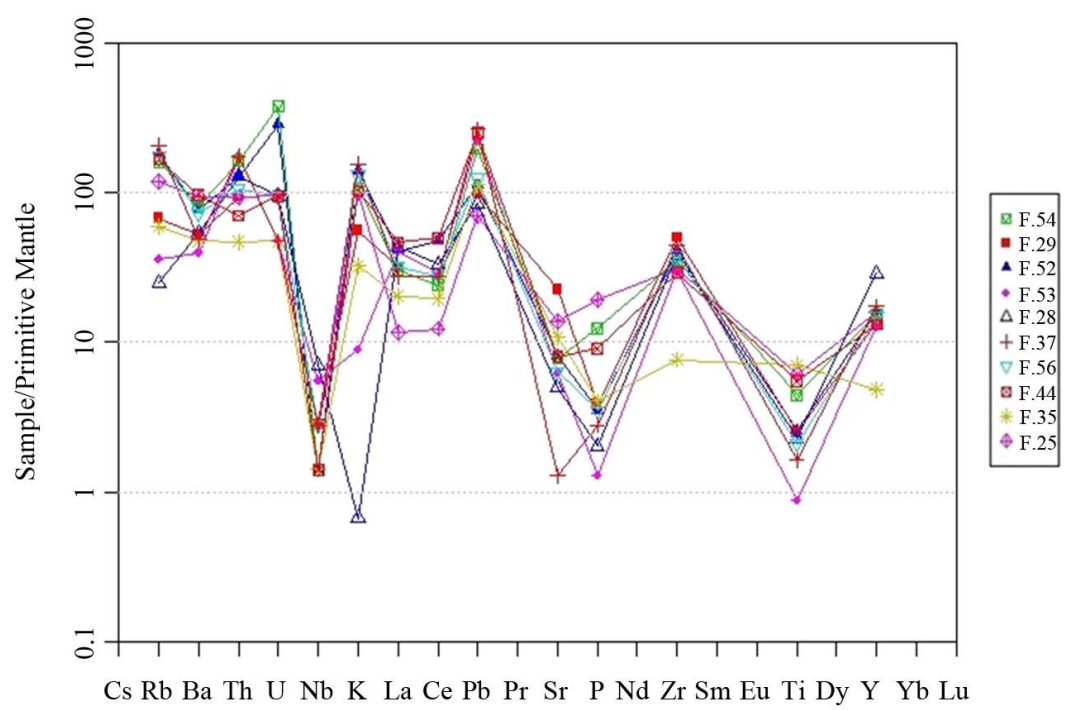

Figure 12. Charts the norm sample of the study area, with primitive mantle (MacDonough \& Sun, 1989) [4].

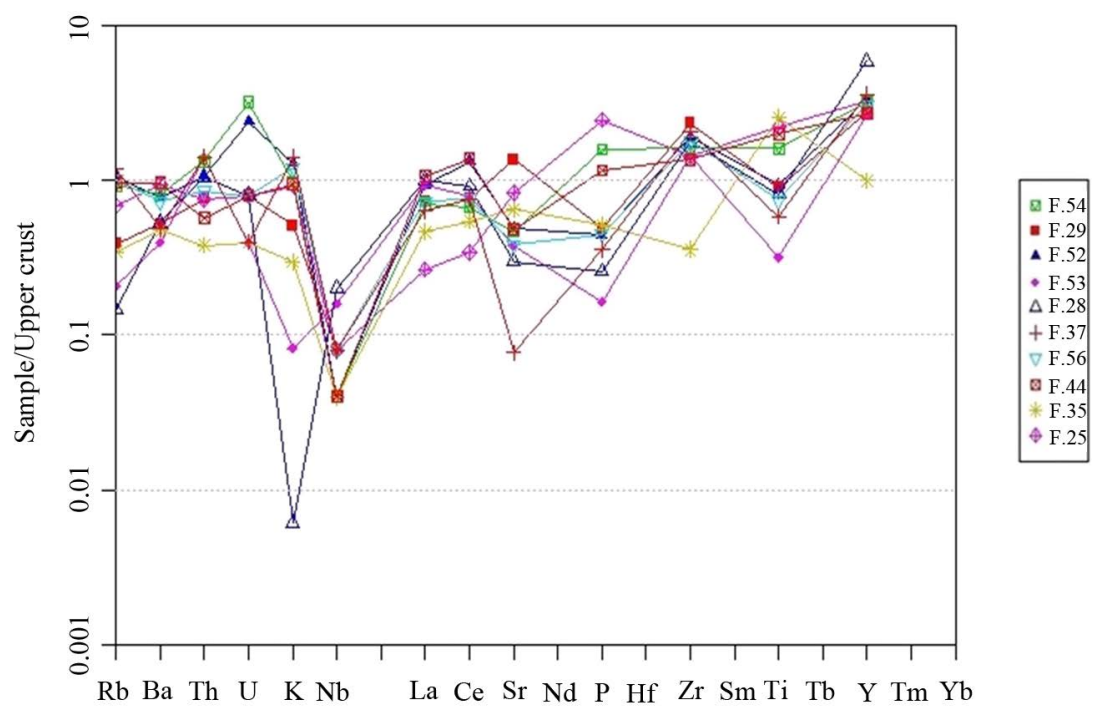

Figure 13. Normalized charts, samples of the study area, with the upper crust [5].

medium-grained texture, and rich hornblende and plagioclase, and the sample-and-white are gray.

These rocks are the main minerals including quartz, feldspar, plagioclase, hornblende, and minor minerals, not including Apec, and sphene, and biotite, and secondary minerals, chlorite and sericite are included. According to the graph, normalized samples studied area, with the upper crust, rocks of the study area belong to this pattern, and most elements are near or on line 1 standard.

\section{Acknowledgements}

Gratitude and thanked from the unconditional and unfailing guidance of venerable professor, Mr. Doctor Ardalan who guided me in compiling this article.

\section{References}

[1] Middlemost, E.A.K. (1985) Magmas and Magmatic Rocks. An Introduction to Igneous Petrology. Longman Group, UK, 73-87. 
[2] Wilson, R. (1990) Igneous Petrogenesis. Unwin Hyman Ltd., 466 p.

[3] Shand, S.J. (1943) Coronas and Coronites. Bull. Geol. Soci. America, No. 56, 247-266.

[4] Sun, S. and McDonough, W.F. (1989) Chemical and Isotopic Systematic of Oceanic Basalts: Implications for Mantle Composition and Processes. Geological Special Publication No. 42, 313-345.

[5] Taylor, R.P. and Mclennan, S.M. (1985) The Continental Crust, Its Composition and Evolution. Black Wall, Oxford, 312 p. 